\title{
Optimalisasi Partisipasi Masyarakat Dalam Pengelolaan Keuangan Desa Bresela Kecamatan Payangan Kabupaten Gianyar
}

\author{
Ni Made Gita Krisnawati,Gede Astrawan, Putu Riana Putri, \\ Ni Made Setiari Marleni, Ni Putu Kristian, Ni Made Ayu Pitri Krisantina \\ Jurusan Akuntansi, Universitas Pendidkan Ganesha, Singaraja, Bali, Indonesia
}

\begin{abstract}
Abstrak
Penelitian ini bertujuan untuk bagaimana menumbuhkan sumber daya manusia di Desa Bresela Kecamatan Payangan Kabupaten Gianyar mengenai pengelolaan dana desa untuk meningkatkan partisipasi masyarakat dalam pembangunan desa dan bagaimana ilmu serta gambaran umum mengenai penganggaran daerah guna meningkatkan sumber daya manusia penduduk Desa Bresela Kecamatan Payangan Kabupaten Gianyar. Berdasarkan hasil penelitian informasi pengelolaan dana desa tersebut disosialisasikan kepada masyarakat Desa Bresela melalui sosialisasi oleh instansi pemerintah yang berkaitan dengan pengelolaan dana desa. Anggaran merupakan daftar pernyataan rinci tentang jenis dan jumlah penerimaan, jenis dan pengeluaran negara yang diharapkan dalam jangka waktu satu tahun tertentu, yang selanjutnya disebut Anggaran Pendapatan dan Belanja Negara di tingkat pusat dan Anggaran Pendapatan dan Belanja Daerah di tingkat daerah. Proses penyusunan Anggaran Pendapatan dan Belanja Daerah (APBD) harus sesuai dengan siklus anggaran dan merupakan suatu kegiatan yang menyuruh dan terpadu.
\end{abstract}

Kata kunci: Optimalisasi, Pengelolaan, Keuangan

\section{Abstract}

This study aims to how to grow human resources in the Bresela Village, Payangan District, Gianyar Regency regarding the management of village funds to increase community participation in village development and how knowledge and general picture of regional budgeting in order to increase the human capital of the residents of Bresela Village, Payangan District, Gianyar Regency. Based on the research results, the information on village fund management was socialized to the people of Bresela Village through socialization by government agencies relating to village fund management. The budget is a list of detailed statements about the types and amounts of state revenues, types and expenditures expected within a certain year, hereinafter referred to as the State Budget at the national level and the Regional Budget at the regional level. The process of preparing the Regional Revenue and Expenditure Budget (APBD) must be in accordance with the budget cycle and is an ordered and integrated activity.

\section{Keywords : Optimization, Management, Finance}

\section{Pendahuluan}

Pembangunan dalam suatu desa sangat mempengaruhi masyarakat adil dan makmur merata material dan spiritual. Maka dari itu pemerintah memberikan perhatian terhadap pelaksanaan pembangunan desa agar dapat memberikan hasil nyata, dalam arti adanya peningkatan taraf hidup masyarakat disuatu pihak dan pada pihak lain munculnya semangat dari masyarakat untuk pembangunan yang diwujudkan dalam bentuk partisipasi masyarakat.

Keterlibatan masyarakat sangat penting dalam pembangunan, karena pembangunan yang selalu menekankan peranan pemerintah mengakibatkan tidak adanya partisipasi dari masyarakat dan mengakibatkan masyarakat tidak mengetahui sistem pengelolaan dana desa dalam hal penganggaran untuk pembangunan desa. Pelaksanaan ini untuk mengutamakan kepentingan masyarakat dalam pelaksanaan program-program pembangunan, dimana memberikan peluang seluas-luasnya kepada masyarakat untuk mengarahkan sumber daya, potensi, merencanakan serta membuat keputusan dan mengevaluasi kegiatan-kegiatan pembangunan yang akan mensejahterakan masyarakat.

Desa Bresela di Kecamatan Payangan Kabupaten Gianyar dalam kegiatan pembangunan seperti membangun lapangan voly dan pembangunan yang lain. Lapangan voly tersebut biasanya digunakan sebagai tempat penggalian dana desa dimana lapangan 
voly tersebut sering diadakan tournament voly Desa Bresela Kecamatan Payangan Kabupaten Gianyar. Maka visi dan misi yang harus di capai untuk menyelesaikan lapangan tersebut dengan semaksimal mungkin dengan waktu yang sudah di perhitungkan dalam penyelesaiaan lapangan tersebut. Dalam menunjang visi dan misi tersebut, maka di perlukan partisipasi masyarakat dalam proses pembangunan mulai dari perencanaan, pelaksanaan, sampai pada evaluasi hasil pembangunan, hal tersebut sangat penting di tingkat desa. Karena kurangnya pula ilmu yang dimiliki penduduk setempat mengenai penganggaran daerah sehingga kurangnya minat dari para penduduk untuk berpartisipasi dalam organisasi pemerintahan di Desa Bresela Kecamatan Payangan Kabupaten Gianyar.

Visi dan misi tersebut belum maksimal karena partisipasi masyarakat masih kurang karena kurangnya peranan pemerintah dan pengetahuan mengenai pengelolaan dana desa pada masyarakat untuk berpartisipasi dalam pembangunan, pola pikir masyarakat yang masa bodoh menganggap pembangunan itu merupakan tanggung jawab pemerintah. Dalam pembangunan desa ini seharusnya peranan masyakat yang banyak, tetapi kenyataan yang didapati di lapangan berbeda dengan apa yang diharapkan. Padahal masih banyak pembangunan-pembangunan desa yang belum di selesaikan seperti jalan ke sawah maupun jalan-jalan yang berlubang.

Dengan memperhatikan latar belakang tersebut, agar dalam penulisan ini penulis memperoleh hasil yang diinginkan, maka penulis mengemukakan beberapa rumusan masalah. Rumusan masalah itu adalah bagaimana menumbuhkan sumber daya manusia di Desa Bresela Kecamatan Payangan Kabupaten Gianyar mengenai pengelolaan dana desa untuk meningkatkan partisipasi masyarakat dalam pembangunan desa dan bagaimana ilmu serta gambaran umum mengenai penganggaran daerah guna meningkatkan sumber daya manusia penduduk Desa Bresela Kecamatan Payangan Kabupaten Gianyar.

\section{Pembahasan}

2.1 Menumbuhkan Sumber Daya Manusia Di Desa Bresela Kecamatan Payangan Kabupaten Gianyar Mengenai Pengelolaan Dana Desa Untuk Meningkatkan Partisipasi Masyarakat Dalam Pembangunan Desa

Kurangnya partisipasi masyarakat dengan pengelolaan dana desa dikarenakan kurangnya sumber daya manusia atau kurangnya pengetahuan masyarakat terhadap pengelolaan dana desa. Sehingga masyarakat merasa enggan untuk ikut serta dalam pembangunan desa dalam halnya mengelola dana desa. Dalam menumbuhkan partisipasi masyarakat untuk dapat ikut terjun langsung dalam pengelolaan dana desa diperlukan suatu pemberdayaan masyarakat khususnya mengenai pengelolaan dana desa tersebut baik dalam penganggaran dana desa, karakteristik penggunaan akuntansi dalam dana desa maupun dalam perhitungan pajak.

Menurut Stewart (1998:17) pemberdayaan adalah suatu pemberi kekuasaan, pengalihkan kekuatan atau mendelegasikan orientasi atau kewenangan kepada pihak lain atau memberi kemampuan atau keberdayaan. Proses pemberdayaan pencapaian tujuan, dengan pendelegasian otoritas, menciptakan sistem atau prosedur akan mempercepat pencapaian tujuan-tujuan organisasi. Pemberdayaan tersebut memerlukan pengungkapan pandangan pimpinan dengan jelas dan jujur yang bermaksud mendorong aparat dalam memberikan pelayanan yang bermutu. Pemberdayaan menjadi sebuah proses menuju peningkatan kekuasaan, kemampuan dan daya. Lebih lanjut Stewart (1998:29) mengatakan:

1. Pemberdayaan dapat meningkatkan pelayanan kepada masyarakat.

2. Pemberdayaan juga memberi kepada staf rasa berprestasi yang lebih besar sehingga dapat meningkatkan motivasi.

3. Pemberdayaan juga memberikan manfaat besar bagi organisasi dimanasalah satunya adalah bertambanya efektivitas organisasi.

Menurut Mubyarto (1993:20-41) menekankan dalam proses pemberdayaan masyarakat diarahkan pada pengembangan sumberdaya manusia (di pedesaan), penciptaan peluang berusaha sesuai dengan keinginan masyarakat. Masyarakat menentukan jenis usaha, kondisi wilayah yang pada gilirannya dapat menciptakan lembaga 
dan sistem pelayanan dari, oleh dan bentuk masyarakat setempat. Supaya pemberdayaan masyarakat ini kemudian pada pemberdayaan ekonomi rakyat.

Dari beberapa teori mengenai arti dari pemberdayaan dapat dilihat bahwa pemberdayaan masyarakat sangat penting untuk memajukan kesejahteraan masyarakat desa dengan sumber daya yang baik. Jadi masyarakat perlu mengetahui pengelolaan dana desa yaitu sebagai berikut:

Pengelolaan Dana Desa Menurut Kebijakan Pengelolaan Keuangan Desa Berdasarkan Permendagri No. 113 Tahun 2014

Azas Pengelolaan Keuangan Desa

1. Transparansi

Terbuka, tidak ada yang ditutupi

2. Akuntabel

Dapat dipertanggungjawabkan, Administransi, Moral, Hukum

3. Partisipatif

Mengutamakan keterlibatan masyarakat

4. Tertib dan disiplin anggaran

Pengelolaan Dana Desa

Konsisten, tepat waktu, tepat jumlah dan taat azas

1. Perencanaan

a. Sekretaris desa menyusun rapat pertemuan desa tentang APB Desa berdasarkan RKP Desa.

b. Kepala desa bersama BPD untuk membahas dan menyepakati.

c. Paling lambat bulan oktober tahun berjalan.

d. Disampaikan kepada bupati atau wali kota melalui camat paling lambat 3 hari setelah disepakati.

e. Hasil evaluasi paling lama 20 hari kerja.

f. Tidak memberi hasil evaluasi, peraturan desa berlaku.

g. Hasil evaluasi tidak sesuai, kepala desa menyempurnakan paling lama 7 hari kerja

h. Apabila evaluasi tidak ditinjau oleh kepala desa dan menetapkan peraturan desa, dibatalkan dengan kepala bupati/walikota dan menyatakan berlakunya peraturan APB Desa tahun sebelumnya.

i. Pembatalan, hanya untuk operasional penyelenggaraan pemerintah desa.

j. Setelah pembatalan, paling lama 7 hari kerja mencabut peraturan desa.

k. Dalam hal evaluasi di delegasikan kepada Camat, Prosesnya sama dengan evaluasi oleh Bupati, namun apabila ada pembatalannya tetap oleh Bupati.

2. Pelaksanaan

I. Pendelegasian di atur dalam peraturan Bupati/Wali Kota

a. Penerimaan dan Pengeluaran Desa:

1. Melalui Rekening Kas Desa

2. Didukung dengan bukti yang lengkap dan sah

b. Belum memiliki pelayanan perbankan ditetapkan oleh Pemda

c. Pemdes dilarang melakukan pungutan selain yang ditetapkan dalam peraturan desa

d. Bendahara dapat menyimpan uang dalam kas desa dan besarannya ditetapkan dengan peraturan bupati atau walikota.

e. Pengeluaran desa yang mengakibatkan beban APBD Desa:

1. Tidak dapat dilakukan sebelum ditetapkan menjadi peraturan desa

2. Tidak termasuk belanja pegawai yang bersifat mengikat dan operasional perkantoran yang ditetapkan dengan peraturan kepala desa.

f. Penggunaan biaya tak terduga:

1. Harus dibuat rincian RAB

2. Disahkan Kepala Desa

g. Pengadaan barang dan/atau jasa di Desa diatur dengan Peraturan Bupati/Wali Kota

h. Pelaksana kegiatan

1. Mengajukan pendanaan untuk kegiatan disertai dokumen.

2. RAB diverifikasi oleh sekretaris desa, disahkan kepala desa. 
3. Bertanggung jawab terhadap pengeluaran (Buku Pembantu Kas Kegiatan).

4. Mengajukan Surat Permintaan Pembayaran kepada Kepala Desa.

5. Surat Permintaan Pembayaran dibuat setelah barang dan/atau jasa diterima.

6. Pengajuan surat Permintaan Pembayaran terdisi atas:
a) Surat permintaan pembayaran
b) Pernyataan tanggungjawab belanja
c) Lampiran bukti transaksi

i. Perubahan APB Desa

1. Perubahan APBDesa
a) Keadaan yang menyebabkan harus dilakukan penggeseran antar jenis belanja.
b) Keadaan yang menyebabkan sisa lebih perhitungan penganggaran tahun sebelumnya harus digunakan dalam tahun berjalan.
c) Terjadi penambahan dan/atau pengurangan dalam pendapatan desa pada tahun berjalan.
d) Terjadi peristiwa khusus seperti bencana alam, krisis politik, krisis ekonomi, dan/atau kerusuhan sosial yang berkepanjangan.
e) Perubahan mendasar atas kebijakan pemerintah dan Pemda.

2. Perubahan APB Desa hanya dapat dilakukan 1 kali dalam 1 tahun kecuali dalam keadaan darurat dan/atau luar biasa.

3. Tata cara pengajuan perubahaan APB Desa adalah sama dengan tata cara penetapan pelaksanaan APB Desa.

4. Dalam hal Bantuan Keuangan dari APBD Provinsi \& APBD Kabupaten atau Kota serta hibah \& bantuan pihak ketiga yang tidak mengikat ke desa disalurkan setelah ditetapkannya peraturan desa tentang perubahan APBDesa, perubahan diatur dengan peraturan Kepala Desa tentang perubahan APBDesa

5. Perubahan APBDesa diinformaskan kepada BPD

j. Penatausahaan

1. Wajib dilaksanakan oleh bendahara desa

2. Pencatatan setiap penerimaan dan pengeluaran

3. Melakukan tutup buku setiap akhir bulan

4. Mempertanggungjawabkan uang melalui laporan

5. Laporan disampaikan setiap bulan kepada Kepala Desa paling lambat tanggal 10 bulan berikutnya

6. Menggunakan:
a) Buku kas umum
b) Buku kas pembantu pajak
c) Buku kas bank

k. Laporan \& Pertanggungjawaban

1. Kepala Desa kepada Bupati/Walkota melalui Camat

2. Laporan realisasi pelaksanaan APBDesa :
a) Laporan semester pertama yaitu paling lambat akhir bulan Juli tahun bulan berjalan
b) Laporan semester akhir tahun yaitu paling lambat akhir bulan Januari tahun berikutnya

3. Laporan pertanggungjawaban realisasi pelaksanaan APBDesa, disampaikan setiap akhir tahun anggaran (paling lambat satu bulan setelah akhir tahun anggaran)
a) Pendapatan, belanja, pembiayaan
b) Ditetapkan dengan peraturan desa
c) Dilampiri format laporan:
1) Pertanggungjawaban realisasi pelaksanaan APBDesa tahun berkenaan
2) Kekayaan milik desa per 31 Desember tahun berkenaan
3) Program pemerintah dan Pemda yang masuk ke desa

Setelah mengetahui pengelolaan dana desa yang berlaku maka informasi pengelolaan dana desa tersebut disosialisasikan kepada masyarakat Desa Bresela melalui sosialisasi 
oleh instansi pemerintah yang berkaitan dengan pengelolaan dana desa. Dan dengan diadakannya pelatihan yang diadakan dan didanai oleh pemerintah desa kepada masyarakat mengenai pengelolaan dana desa.

\subsection{Gambaran Umum Mengenai Penganggaran Daerah Kepada Desa Bresela Kecamatan Payangan Kabupaten Gianyar}

Anggaran merupakan daftar pernyataan rinci tentang jenis dan jumlah penerimaan, jenis dan pengeluaran negara yang diharapkan dalam jangka waktu satu tahun tertentu, yang selanjutnya disebut Anggaran Pendapatan dan Belanja Negara di tingkat pusat dan Anggaran Pendapatan dan Belanja Daerah di tingkat daerah. Anggaran Daerah adalah suatu bentuk kongkrit rencana kerja keuangan daerah yang komprehensif yang mengaitkan penerimaan dan pengeluaran pemerintah daerah yang dinyatakan dalam bentuk uang untuk mencapai tujuan atau target yang direncanakan dalam jangka waktu tertentu satu tahun anggaran. Mulia dalam Adisasmita menjelaskan secara rinci bahwa Anggaran Pendapatan dan Belanja Daerah adalah suatu hal yang sangat penting karena APBD itu :

a. Menentukan jumlah pajak yang dibebankan kepada rakyat daerah yang bersangkutan.

b. Merupakan suatu sarana untuk mewujudkan otonomi daerah yang nyata dan bertanggung jawab.

c. Memberikan isi dan arti kepada tanggung jawab pemerintah daerah dan kepala daerah, karena APBD itu menggambarkan seluruh kebijakan pemerintah daerah.

d. Merupakan suatu sarana untuk melaksanakan pengawasan terhadap daerah dengan cara yang lebih mudah dan berhasil guna.

e. Merupakan suatu pemberian kewenangan kepada kepala daerah untuk melakukan penyelenggaraan keuangan daerah.

Anggaran Negara menurut John F.Due adalah suatu pernyataan tentang perkiraan pengeluaran dan penerimaan yang diharapkan akan terjadi dalam suatu periode di masa depan, serta data dari pengeluaran dan penerimaan yang sungguh-sungguh terjadi di masa lalu. Anggaran Negara secara lebih rinci dapat dikatakan bahwa :

a. Dengan anggaran negara dapat diketahui tercapai atau tidaknya kebijakan pemerintah di masa lalu dan maju atau mundurnya kebijakan yang hendak dicapai pemerintah di masa yang akan datang.

b. Dengan anggaran negara dapat diketahui realisasi pelaksanaan kebijakan pemerintah di masa lalu.

c. Anggaran negara merupakan gambaran dari kebijakan pemerintah yang dinyatakan dalam ukuran uang, baik kebijakan pengeluaran pemerintah untuk suatu periode di masa depan maupun kebijakan penerimaan untuk pengeluaran tersebut.

Fungsi Anggaran Daerah

Penyelenggaraan urusan pemerintahan yang menjadi kewenangan pemerintah di daerah didanai dari dan atas beban APBN. Anggaran Pendapatan dan Belanja Daerah memiliki beberapa fungsi sebagai berikut :

a. Fungsi otorisasi, mengandung arti bahwa anggaran daerah menjadi dasar untuk melaksanakan pendapatan dan belanja pada tahun yang bersangkutan.

b. Fungsi perencanaan, mengandung arti bahwa anggaran daerah menjadi pedoman bagi manajemen dalam merencanakan kegiatan pada tahun yang bersangkutan.

c. Fungsi pengawasan, mengandung arti bahwa anggaran daerah menjadi pedoman untuk menilai apakah kegiatan penyelenggaraan pemerintah daerah sesuai dengan ketentuan yang telah ditetapkan.

d. Fungsi alokasi, mengandung arti bahwa anggaran daerah harus diarahkan untuk menciptakan lapangan kerja atau mengurangi pengangguran dan pemborosan sumber daya serta meningkatkan efisiensi dan efektivitas perekonomian.

e. Fungsi distribusi, mengandung arti bahwa kebijakan anggaran daerah harus memperhatikan rasa keadilan dan kepatuhan.

f. Fungsi stabilisasi, mengandung arti bahwa anggaran pemerintah daerah menjadi alat untuk memelihara dan mengupayakan keseimbangan fundamental perekonomian daerah. 


\section{Prinsip-Prinsip Anggaran Daerah}

Berdasar atas sasaran dan ketersediaan anggaran, prinsip efisiensi dapat dibagi dalam dua sudut pandang, yaitu :

a. Efisiensi yang berorientasi anggaran. Jadi dengan anggaran yang ada diusahakan mampu membiayai berbagai macam bentuk kegiatan yang berguna di dalam menjalankan kehidupan pemerintahan, pembangunan dan kemasyarakatan.

b. Efisien yang berorientasi kegiatan. Dengan adanya prioritas kegiatan maka pemrintah melakukan pengelolaan yang baik terhadap anggaran dengan prioritas kegiatan pembangunan harus terlaksana.

Dengan efisien yang dilakukan maka banyak kegiatan pembangunan yang dapat tercakup dari ketersdiaan anggaran yang ada. Dengan demikian prinsip efisien dalam anggaran daerah diperlukan penganggaran yang sesuai dengan kebutuhan daerah bersangkutan. Menurut Mardiasmo (2002) dalam Adiputra dan Saputra (2014;31) dan Kaweder, Rohman dan Handayani (2008:154) didalam penyusunan APBD harus memperhatikan prinsip Anggaran yang baik agar tidak terjadi penyimpangan. Prinsip-prinsip tersebut adalah :

I. Partisipasi Masyarakat

Hal ini mengandung makna bahwa pengambilan keputusan dalam proses penyusunan dan penetapan APBD sedapat mungkin melibatkan pertisipasi masyarakat, sehingga masyarakat mengetahui akan hak dan kewajiban dalam pelaksanaan APBD.

II. Transparansi dan Akuntabilitas Anggaran

APBD yang disusun harus dapat menyajikan informasi secara terbuka dan mudah diakses oleh masyarakat meliputi tujuan,sasaran, sumber pendanaan pada setiap jenis belanja serta korelasi antara besaran anggaran dengan manfaat dan hasil yang ingin dicapai dari suatu kegiatan yang dianggarkan.

III. Disiplin Anggaran

Beberapa prinsip dalam disiplin anggaran yang perlu diperhatikan antara lain :

1. Pendapatan yang direncanakan merupakan pikiran yang terukur secara rasional yang dapat dicapai untuk setiap sumber pendapatan, sedangkan belanja yang dianggarkan merupakan batas tertinggi pengeluaran belanja.

2. Penganggaran pengeluaran harus didukung dengan adanya kepastian tersedianya penerimaan dalam jumlah yang cukup dan tidak dibenarkan melaksanakan kegiatan yang belum tersedia atau tidak mencukupi kredit anggarannya dalam APBD/Perubahan APBD.

3. Semua penerimaan dan pengeluaran daerah dalam tahun anggaran yang bersangkutan harus dianggarkan dalam APBD dan dilakukan melaui rekening kas umum daerah.

IV. Keadilan Anggaran

Pajak daerah, restibusi daerah, dan penggunaan daerah lainnya yang dibebankan kepada masyarakat dan harus mempertimbangkan kemampuan masyarakat untuk membayar. Selain daripada itu dalam mengalokasikan belanja daerah, harus mempertimbangkan keadilan dan pemerataan agar dapat dinikmati oleh seluruh lapisan masyarakat tanpa diskriminasi pemberian pelayanan.

V. Efisiensi dan Efektivitas Anggaran

Untuk meningkatkan pelayanan dan kesejahteraan masyarakat harus memperhatikan dua hal, yaitu :

1) Tujuan, sasaran, hasil dan manfaat, serta indikator kinerja yang ingin dicapai

2) Penetapan prioritas kegiatan dan penghitungan beban kinerja.

VI. Taat Azas

APBD sebagai rencana keuangan tahunan pemerintah daerah ditetapkan denga peraturan daerah, memperhatikan :

1) APBD tidak bertentangan dengan peraturan perundang-undangan yang lebih tinggi.

2) APBD tidak bertentangan dengan kepentingan umum.

3) APBD tidak bertentangan dengan peraturan daerah lainnya. 


\section{Format Anggaran}

Pada dasarnya APBD disusun berdasarkan format anggaran deficit. Selisih antara pendapatan dan belanja mengakibatkan terjadinya surplus dan defisit anggaran. Apabila terjadi surplus, daerah dapat membentuk Dana Cadangan, sedangkan jika terjadi defisit, dapat ditutupi melalui sumber pembiayaan pinjaman dan atau penerbitan obligasi daerah sesuai dengan ketentuan perundang-undangan yang berlaku.

Konsep Akuntabilitas Anggaran

Saat ini reformasi menuju penganggaran yang berorientasi kepada hasil sudah dimulai menjadi tren perkembangan di banyak negara. Reformasi sektor publik yang ditandai dengan munculnya era New Public Management menjadi upaya mewirausahakan pemerintah yang berorientasi kepada hassil, pelayanan publik, dan akuntabilitas. Baswir (1999) dalam Adiputra dan Saputra (2014:32) dalam pelaksanaan akuntabilitas di lingkungan organisasi sektor publik, perlu diperhatikan prinsip-prinsip sebagai berikut :

a. Harus ada komitmen dan pimpinan dan seluruh staf instansi untuk melakukan pelaksanaan misi agar akuntabel

b. Harus merupakan suatu sistem yang dapat menjamin penggunaan sumber-sumber daya secara konsisten dengan peraturan perundang-undangan yang berlaku

c. Harus dapat menunjukakan tingkat pencapaian tujuan dan sasaran yang telah ditetapkan

d. Harus berorientasi pada pencapaian visi dan misi serta hasil dan manfaat yang diperoleh

e. Harus jujur, obyektif, transparan dan inovatif sebagai katalisator perubahan manajemen instansi pemerintah dalam bentuk pemutakhiran metode dan teknik pengukuran kinerja dan penyusunan kinerja dan penyusunan laporan akuntabilitas.

\section{Perencanaan Pembangunan Daerah}

Sistem perencanaan pembangunan daerah mengalami perubahan mendasar dengan tuntutan bidang politik, pemerintah dan pengelolaan keuangan negara. Sistem pemilihan baik presiden dan wakil dan kepala daerah pada era demokrasi ini dipilih secara langsung. Paparan mengenai visi, misi dan program terutama kepala daerah terpilih akan menjadi bahan utanma penyusunan agenda kerja selama 5 tahun ke depan yang dituangkan dalam dokumen Rencana Pembangunan Jangka Menengah Daerah (RPJND). Berdasarkan Undang-undang No.25 tahun 2004 tentang Sistem Perencanaan Pembangunan nasional, juga.menegaskan bahwa Rencana Pembangunan Jangka Menengah Daerah (RPJM-D) disusun berpedoman pada Rencana Jangka Panjanga (RPJP-D) dan memperhatikan Rencana Pembangunan Jangka Panjang (RPJP 2005 - 2025 dan Rencana Jangka Menengah Nasional (RPJM-Nas).

Anggaran Berbasis Kinerja

Undang -undang Nomor 32 tahun 2004 tentang Pemerintahan Daerah dan Undangundang Nomor 33 tahun 2004 tentang penimbangan keuangan antara pemerintah pusat dan pemerintah daerah membuka peluang yang luas bagi daerah untuk mengembangkan dan membangun daerahnya sesuai dengan kebutuhan dan prioritasnya masing-masing. Dengan berlakunya kedua undang-undang tersebut membawa konsekuensi bagi daerah dalam bentuk pertanggungjawaban atas pengalokasian dana yang dimiliki dengan cara yang efisiensi dan efektif, khususnya dalam upaya peningkatan kesejahteraan dan pelayanaan umum kepada masyarakat. Dengan membangun suatu sistem penganggaran yang dapat memadukan perencanaan kinerja dengan anggaran tahunan akan terlihat adanya keterkaitan antara dana yang tersedia dengan hasil yang diharapkan. Sistem penganggaran ini disebut dengan Anggaran Berbasis Kinerja (ABK).

1. Indikator Kinerja

Bagian yang terpenting dalam penyusunan anggaran berbasis kinerja (ABK) adalah menetapkan ukuran atau indikator keberhasilan sasaran dari fungsi-fungsi belanja. Pencapaian kinerja dapat dituangkan dalam Laporan Akuntabilitas Kinerja Instansi Pemerintah (LAKIP). Informasi dalam laporan LAKIP dapat memberikan kontribusi pada :

a. Pengambilan keputusan yang lebih baik yaitu dengan menyediakan informasi kepada pemimpin dalam melaksanakan fungsi pengendalian. 
b. Penilaian kinerja dengan menghubungkan dua hal yaitu kinerja individu dengan kinerja organisasi.

c. Akuntabilitas, dengan membantu pimpinan dalam memberikan pertanggungjawaban

d. Pemberian pelayanan, dengan peningkatan kinerja layanan public

e. Partisipasi publik dapat dapat ditingkatkan dengan adanya laporan yang jelas atas ukuran kinerja

f. Perbaikan penanganan masalah masyarakat dengan jalan memberikan pertimbangan kepada masyarakat guna memberikan jasa layanan yang lebih nyata dan spesifik.

Penentuan indikator kinerja harus memenuhi kriteria-kriteria sebagai berikut :

a. Spesifik. Berarti unik, menggambarkan obyek/subyek tertentu, tidak berdwimakna atau diinterprestasikan lain

b. Dapat diukur. Secara obyektif dapat diukur baik yang bersifat kuantitatif maupun kualitatif

c. Relevan. Indikator kinerja sebagai alat ukur harus terkait dengan apa yang diukur dan menggunakan keadaan subyek yang diukur, bermanfaat bagi pengambilan keputusan

d. Tidak bias. Tidak memberikan kesan atau arti yang menyesatkan

2. Konsep Input, Output dan Outcome

Kawedar, Rohman dan Handayani (2008:120) dalam rangka membangun ABK maka dibutuhkan perencanaan berbasis kinerja sehingga diperlukan identifikasi indikator-indikator memulai sistem pengumpulan dan pengolahan data atau informasi untuk menentukan capaian tingkat kinerja kegiatan. Berikut ini akan dijelaskan beberapa indikator kinerja.

a. Masukan (Input)

Masukan merupakan sumber daya yang digunakan untuk memebrikan pelayanan pemerintah. Indikator masukan meliputi biaya personil,biaya operasional,biaya modal dan lainnya yang secara total di tuangkan dalam belanja langsung yang terdiri dari 3 jenis belanja yaitu : belanja pegawai, belanja barang dan jasa, dan belanja modal.

b. Keluaran (Output)

Keluaran merupakan produk dari suatu aktivitas atau kegiatan yang dihasilkan Satuan Kerja Perangkat Daerah yang bersangkutan. Indikator keluran dapat menjadi landasan untuk menilai kemajuan suatu kegiatan apabila target kinerjanya dikaitkan dengan sasaran-sasaran kegiatan yang terdefinisi dengan baik dan terukur indikator keularan harus sesuai dengan tugas pokok dan fungsi unit yang bersangkutan.

c. Hasil (Outcome)

Indikator outcome menggambarkan hasil nyata dari keluaran suatu kegiatan. Pengukuran indikator hasil seringkali rancu dengan indikator output. Indikator outcome merupakan ukuran kinerja dari program dalam memenuhi sasarannya. Pencapaian sasaran dapat ditentukan dalam suatu satu tahun anggaran, beberapa tahun anggaran, atau periode pemerintahan.

Dasar Hukum Anggaran Berbasis Kinerja

Adiputra dan Saputra (2014:34) Sejalan dengan perlunya dilakukan reformasi sektor publik, saat ini telah dikeluarkan Undang-Undang dan Peraturan Pemerintah yang mengatur tentang Anggaran adalah sebagai berikut :

a. Undang- Undang Nomor 17 Tahun 2003 : Tentang Keuangan Negara

b. Undang- Undang Nomor 1 Tahun 2004 : Tentang Pembendaharan Negara

c. Undang- Undang Nomor 32Tahun 2004 : Tentang Pemerintahan Daerah

d. Undang- Undang Nomor 33 Tahun 2004 : Tentang Perimbangan Keuangan Antara Pemerintah Pusat dan Pemerintahan Daerah

e. Peraturan Pemerintah Nomor 23 Tahun 2003 : Tentang Pengendalian Jumlah Kumulatif Defisit APBN dan APBD, serta Jumlah Kumulatif Pinjaman Pemerintah Pusat dan Pemrintahan Daerah

f. Kepmendagri Nomor 29 Tahun 2002, Penmendagni Nomor 13 Tahun 2006 dan Permendagni Nomor 59 Tahun 2007 Tentang Pedoman Pengelolaan Keuangan Daerah

Proses Penyusunan Anggaran 
Dalam penyusunan APBD harus berorientasi pada anggaran berbasis kinerja yaitu suatu pendekatan penganggaran yang mengutamakan keluaran dari program dan kegiatan yang akan atau telah di capai sehubungan dengan penggunaan anggaran dengan kuantitas dan kualitas terukur. Adapun proses Anggaran belanja daerah mencangkup: Adisasmita $(2011: 65)$

a. Daftar waktu dan jenis anggaran

b. Masalah-masalah proyeksi penerimaan dan belanja daerah

c. Jenis dan pengaruh peraturan-peraturan anggaran belanja termasuk persyaratan neraca anggaran belanja

d. Batas -batas penerimaan pajak dan batas pengeluaran

e. Anggaran belanja yang fleksiblel atau memperlakukan anggaran belanja terhadap jenis pengeluaran yang berbeda

f. Tingkat dan kelayakan untuk memperuntukan pendapatan pada kategori pengeluaran tertentu.

Dalam penyusunan APBD ditekankan pada penyususnan anggaran yang terpadu yaitu dalam rencana keuangan tahunan dilakukan secara terintegrasi untuk seluruh jenis belanja guna melaksanakan kegiatan pemerintahan yang didasarkan pada prinsip pencapaian efisiensi alokasi dana. Berikut langkah-langkah yang harus dilakukan oleh pemerintah daerah dalam menyususn APBD, yaitu Kaweder, Rohman dan Handayani (2008:159).

a. Penyusunan Kebijakan Umum APBD (KUA) dan Penyusunan Prioritas Dan Platfon Anggaran Sementara (PPAS)

b. Penyusunan dan penyampaian surat edaran Kepala Daerah tentang pedoman penyusunan RKP-SKPD kepada seluruh SKPD

c. Penyusunan rancangan Peraturan Daerah tentang APBD

d. Penyusunan rancangan Peraturan Kepala Daerah tentang penjabaran APBD

e. Penyampaian rancangan Peraturan Daerah tentang APBD dan Peraturan Kepala Daerah tentang Penjabaran APBD

Ibnu Syamsi (1994) dalam Adsasmita (2011:66) proses penyusunan Anggaran Pendapatan dan Belanja Daerah (APBD) harus sesuai dengan siklus anggaran dan merupakan suatu kegiatan yang menyuruh dan terpadu. Periodenya adalah Desember sampai dengan Maret tahun depan berikutnya bulan April APBD dilaksnanakan (atau bulan Januari).

\section{Simpulan dan Saran}

Setelah memperhatikan isi dalam pembahasan di atas, maka dapat kami tarik kesimpulan sebagai berikut:

a) Setelah mengetahui pengelolaan dana desa yang berlaku maka informasi pengelolaan dana desa tersebut disosialisasikan kepada masyarakat Desa Bresela melalui sosialisasi oleh instansi pemerintah yang berkaitan dengan pengelolaan dana desa.

b) Anggaran merupakan daftar pernyataan rinci tentang jenis dan jumlah penerimaan, jenis dan pengeluaran negara yang diharapkan dalam jangka waktu satu tahun tertentu, yang selanjutnya disebut Anggaran Pendapatan dan Belanja Negara di tingkat pusat dan Anggaran Pendapatan dan Belanja Daerah di tingkat daerah.

c) Proses penyusunan Anggaran Pendapatan dan Belanja Daerah (APBD) harus sesuai dengan siklus anggaran dan merupakan suatu kegiatan yang menyuruh dan terpadu.

Disamping itu, diberikan juga saran yakni dengan dibuatnya mini research yang berjudul Optimalisasi Partisipasi Masyarakat Dalam Pengelolaan Keuangan Desa Bresela Kecamatan Payangan Kabupaten Gianyar ini, kami harap dapat bermanfaat bagi yang membacanya. Adapun saran yang ingin kami sampaikan dalam pembuatan mini research ini adalah sebaiknya mini research ini bisa mendapat nilai yang baik dalam penilaian nanti. Karena kami telah bersungguh-sungguh dalam proses pembuatannya dan melakukan yang terbaik demi hasil yang maksimal. 


\section{DAFTAR PUSTAKA}

Prayudi, Aristia dan Adi Kurniawan Saputra. 2016. Akuntansi Pemerintahan. Singaraja : Istiqlal Publishing Group

Direktorat Jenderal Bina Pemerintahan Indonesia. 2016. Kebijakan Pengelolaan Keuangan Desa Berdasarkan Permendagri No. 113 Tahun 2014. Diunduh tanggal 02 Maret 2016. http://www.djpk.depkeu.go.id/wp-content/uploads/2016/03/02.-PengelolanKeuangan-Desa_Kemendagri.pdf 